\title{
EVALUASI PELAKSANAAN DAN PENERAPAN PRINSIP DALAM PENGELOLAAN PERUSAHAAN YANG BAIK (GOOD CORPORATE GOVERNANCE) PADA PT ANEKA TAMBANG TBK
}

\author{
Iswandi $^{1}$; Widya Rahmawati ${ }^{2}$ \\ 1,2 Jurusan Akuntansi, Fakultas Ekonomi dan Bisnis, Bina Nusantara University \\ Jln. K.H. Syahdan No. 9, Kemanggisan, Palmerah, Jakarta Barat 11480
}

\begin{abstract}
In terms of improving corporate performance and the efforts to create a healthy business climate, particularly in state-owned company, the application of the principles of good corporate governance (GCG) needs to be improved. Research conducted at PT Aneka Tambang Tbk is evaluating the application of the principles of GCG is in compliance with regulations applicable or not. In evaluating the data, the author uses descriptive method of research using a case study approach. The author gives a clear picture of the actual state of the object of research by looking at the facts that exist. After the data is obtained, the suitability evaluation based on several sources of theory relevant to the issues discussed. The authors collected data from PT Aneka Tambang Tbk through interviews and direct observation of the parties relating to corporate governance. Based on the evaluation, it can be concluded that PT Aneka Tambang Tbk has applied the principles of good corporate governance and in accordance with the existing parameters of the OECD 2004. With the application of a good and appropriate, effectivity and improved corporate efficiency and welfare of its employees, shareholders, and company stakeholders has also increased. In addition, the results of the evaluation stated that the consultation of shareholders against the company are very important stakeholders and should be maintained in order to create fluency in information exchange and exchange ideas effectively and efficiently.
\end{abstract}

Keywords: corporate governance, GCG principle, consultation

\begin{abstract}
ABSTRAK
Dalam hal meningkatkan kinerja perusahaan dan upaya menciptakan iklim usaha yang sehat, terutama dalam perusahaan BUMN, penerapan prinsip-prinsip good corporate governance (GCG) perlu lebih ditingkatkan. Penelitian yang dilakukan pada PT Aneka Tambang Tbk yaitu mengevaluasi penerapan prinsipprinsip GCG apakah telah sesuai dengan peraturan yang berlaku atau belum. Dalam mengevaluasi data, penulis menggunakan metode deskriptif dengan penelitian menggunakan pendekatan studi kasus. Penulis memberikan gambaran yang jelas tentang keadaan objek penelitian yang sebenarnya dengan melihat faktafakta yang ada. Setelah data diperoleh, dilakukan evaluasi kesesuaian berdasarkan beberapa sumber teori yang relevan dengan masalah yang dibahas. Penulis mengumpulkan data yang diperoleh dari PT Aneka Tambang Tbk melalui wawancara dan observasi langsung pada pihak-pihak yang berkaitan dengan Corporate Governance. Berdasarkan hasil evaluasi, dapat disimpulkan bahwa PT Aneka Tambang Tbk telah menerapkan prinsip Corporate Governance dengan baik dan sesuai dengan parameter yang ada yaitu OECD 2004. Selain itu hasil dari evaluasi menyatakan bahwa konsultasi pemegang saham terhadap pemangku kepentingan perusahaan sangat penting dan harus terjaga demi terciptanya kelancaran dalam bertukar informasi maupun bertukar pikiran secara efektif dan efisien.
\end{abstract}

Kata kunci: corporate governance, prinsip GCG, konsultasi 


\section{PENDAHULUAN}

\section{Latar Belakang}

Pada saat ini kondisi perekonomian di Indonesia sedang menurun, hal ini di akibatkan adanya krisis ekonomi berkepanjangan yang melanda Negara Indonesia. Asian Development Bank (ADB) menyimpulkan bahwa penyebab krisis ekonomi di Negara Asia termasuk Indonesia adalah pengelolaan perusahaan yang belum profesional. Dampaknya, banyak perusahaan yang menurun kualitasnya karena pertumbuhan yang dicapai selama ini hasilnya tidak maksimal di karenakan pertumbuhan perusahaan nya tidak di bangun sesuai prinsip pengelolaan perusahaan yang sehat. Dalam rangka perbaikan ekonomi setelah mengalami krisis ekonomi, konsep Good Corporate Governance (GCG) dengan tata cara kelola perusahaan yang sehat mulai diperkenalkan dan banyak diperbincangkan di berbagai perusahaan.

Dampak dari krisis tersebut menunjukkan banyak perusahaan yang tidak mampu bertahan, salah satu penyebabnya adalah karena pertumbuhan yang dicapai tidak dibangun di atas landasan yang kokoh sesuai dengan pengelolaan perusahaan yang sehat. Suatu perusahaan dalam mengembangkan usahanya menganggap bahwa penerapan prinsip Good Corporate Governance (GCG) merupakan control management atau suatu sarana yang penting sebagai pengendali dalam meningkatkan kinerja perusahaan dan upaya menciptakan perusahaan yang sehat. Corporate governance akan mengatur hubungan antara manajemen perusahan, komisaris, pemegang saham serta para stakeholder lain. Selain itu penerapan konsep Corporate Governance diharapkan dapat meningkatkan profesionalisme dan kesejahteraan para pemegang saham tanpa mengabaikan kepentingan stakeholder.

Good Corporate Govenrance (GCG) merupakan suatu cara untuk menjamin kepentingan stakeholder. Pelaksanaan corporate governance memberikan perlindungan yang kuat untuk hak pemegang saham terutama saham minoritas. Prinsip atau pedoman pelaksanaan corporate governance yang menunjukkan adanya perlindungan yang berdasarkan pada kerangka peraturan tidak hanya di tujukan pada pemegang saham tetapi juga pihak yang terlibat dalam perusahaan. Konsep corporate governance di anjurkan demi terciptanya pengelolaan perusahaan yang lebih transparan bagi semua pengguna data.Melihat sekilas, PT Aneka Tambang Tbk merupakan salah satu perusahaan BUMN yang sudah go public yang bergerak dalam bidang pertambangan. Pemegang Saham (stakeholder) perusahaan ini sekitar 65\% adalah Negara Republik Indonesia dan terkait dengan kebutuhan logam yang bertambah, maka PT. Aneka Tambang Tbk. juga bertumbuh menjadi sebuah perusahaan pertambangan yang dikenal di dalam negeri maupun luar negeri. Sebagai salah satu perusahaan tambang terbesar di Indonesia di sektor logam dan mineral lainnya dan dengan pertumbuhannya yang begitu pesat, PT Aneka Tambang, Tbk perlu menerapkan Good Corporate Governance sebagai pengendali dalam meningkatkan kinerja perusahaan dan upaya menciptakan perusahaan yang sehat yang nantinya akan berpengaruh terhadap pertumbuhan pada perusahaannya.

Mengingat saat ini pemerintah sedang berusaha untuk meningkatkan kinerja perusahaan BUMN, maka sebaiknya pelaksanaan prinsip Corporate Governance perlu lebih di optimalisasikan. Hal tersebut diperlukan untuk menentukan tujuan perusahaan dengan cara pencapaian tujuan serta pemantauan kerja yang dihasilkan. Melihat hal tersebut, penulis menganggap pentingnya penerapan prinsip-prinsip Good Corporate Governance dalam kinerja perusahaan sehingga penulis mengambil bidang ini untuk penulisan skripsi dengan judul Evaluasi Pelaksanaan dan Penerapan Prinsip dalam Pengelolaan Perusahaan yang Baik (Good Corporate Governance) pada PT Aneka Tambang Tbk.

\section{Tujuan dan Manfaat Penelitian}

Tujuan dari penulisan penelitian ini antara lain: (1) mengetahui tentang penerapan dan pelaksanaan Good Corporate Governance pada perusahaan berdasarkan The Organization for Economic Cooperation and Development (OECD); (2) mengidentifikasi adanya kekurangan atau 
kelemahan dalam penerapan Good Corporate Governance berhubungan dengan transparansi atau prinsip-prinsipnya sesuai dengan The Organization for Economic Cooperation and Development (OECD); (3) mengetahui hambatan-hambatan dan faktor apa saja yang menghambat terlaksananya prinsip Good Corporate Governance pada PT. Antam Tbk.; (4) memberikan rekomendasi berdasarkan hasil evaluasi yang telah di lakukan mengacu pada ketentuan yang berlaku yaitu The Organization for Economic Cooperation and Development (OECD) agar perusahaan dapat mengambil atau memakai rekomendasi untuk peningkatan pelaksanaan dalam mengelola perusahaan yang baik.

Adapun manfaat dari penelitian ini adalah: (1) mendapatkan informasi mengenai penerapan prinsip-prinsip Good Corporate Governance; (2) memahami hal-hal yang berkaitan dengan prinsipprinsip Good Corporate Governance; (3) meningkatkan implementasi penerapan prinsip-prinsip Corporate Governance; (4) mengetahui dan mempraktekkan ilmu mengenai penerapan prinsip Corporate Governance dalam dunia kerja atau perusahaan.

\section{Landasan Teori}

Menurut Tjager (2003) mendefinisikan bahwa corporate governance: "a set of rules that define the relationship between shareholders, managers, creditors, the government, employees, and other internal and external stakeholderin respect to their rights and responsibility”. (p.35). Seperangkat aturan yang menunjukkan hubungan antara pemegang saham, manajer, kreditor, pemerintah, karyawan, terhadap hak dan tanggung jawab mereka. Menurut Organization for Economic Cooperation and Development (OECD) dalam Bapepam (2002), "Corporate Governance is the system by which business corporations are directed and controlled. The corporate governance structure specifies the distribution of rights and responsibilities among different participants in the corporation, such as the board, the managers, shareholders and other stakeholders, and spells out the rules and procedure for making decision on corporate affair" (p.2).

Menurut Tangkilisan (2003), World Bank mendefinisikan GCG adalah "kumpulan hukum, peraturan dan kaidah-kaidah yang wajib di penuhi yang dapat mendorong kinerja sumber-sumber perusahaan bekerja secara efisien, menghasilkan nilai ekonomi jangka panjang yang berkesinambungan bagi para pemegang saham maupun masyarakat sekitar secara keseluruhan” (p.12). Menurut Shleifer \& Vishny (1997), GCG adalah “...the ways in which suppliers of finance to corporations assure themselves of getting a return on their investment” (p.3). Rezaee (2007) mendefinisikan GCG yaitu "...is a process effected by legal, regulatory, contractual, and marketbased mechanisms and best practices to create ubstantial shareholders value while protecting the interest of other shareholders" (p.3).

Forum for Corporate Governance in Indonesia (FCGI, n.d.) mendefinisikan corporate governance sebagai “...seperangkat peraturan yang mengatur hubungan antara pemegang, pengurus perusahaan, pihak kreditur, pemerintah, karyawan, serta para pemegang kepentingan eksternal lainnya yang berkaitan dengan hak-hak dan kewajiban mereka atau dengan kata lain suatu sistem yang mengendalikan perusahaan” (p.3). Menurut Komite Cadburry (1992), "GCG adalah prinsip yang mengarahkan dan mengendalikan perusahaan agar mencapai keseimbangan antara kekuatan serta kewenangan perusahaan dalam memberikan pertanggungjawabannya kepada para shareholders khususnya, dan stakeholders pada umumnya” (p.3).

Di Indonesia,secara harfiah Good Corporate Governance merupakan: (1) suatu struktur yang mengatur pola hubungan harmonis tentang peran dewan komisaris, direksi, pemegang saham dan para stakeholder lainnya; (2) suatu sistem pengecekan dan perimbangan kewenangan atas pengendalian perusahaan yang dapat membatasi munculnya dua peluang: pengelolaan yang salah dan penyalahgunaan aset perusahaan; (3) suatu proses yang transparan atas penentuan tujuan perusahaan, pencapaian, berikut pengukuran kinerjanya. 
Dari beberapa teori berkaitan dengan corporate governance, maka dapat disimpulkan bahwa terdapat beberapa prinsip yang selalu menyertai good corporate governance, yaitu: (1) transparansi, merupakan prinsip dasar untuk menjaga obyektivitas dalam menjalankan bisnis, perusahaan harus menyediakan informasi yang material dan relevan dengan cara yang mudah diakses dan dipahami oleh pemangku kepentingan. Perusahaan harus mengambil inisiatif untuk mengungkapkan tidak hanya masalah yang di syaratkan oleh peraaturan perundang-undangan, tetapi juga hal yang penting untuk pengambilan keputusan oleh pemegang saham. (2) akuntabilitas, prinsip dasar perusahaan harus dapatmempertanggungjawabkan kinerjanya secara transparan dan wajar. Untuk itu perusahaan harus dikelola secara benar, terukur, dan sesuai dengan kepentingan perusahaan dengan tetap memperhitungkan kepentingan pemegang saham dan pemangku kepentingan lain. Akuntabilitas merupakan prasyarat yang diperlukan untuk mencapai kinerja yang berkesinambungan. (3) tanggung jawab, prinsip dasar perusahaan harus mematuhi peraturan perundang-undangan serta melaksanakan tanggung jawab terhadap masyarakat dan lingkungan sehingga dapat terpelihara kesinambungan usaha dalam jangka panjang dan mendapat pengakuan sebagai good corporate citizen. (4) kemandirian, prinsip dasar untuk melaksanakan asas GCG, perusahaan harus di kelola secara independen sehingga masing-masing organ perusahaan tidak saling mendominasi dan tidak dapat di intervensi oleh pihak lain. (5) kesetaraan dan kewajaran, prinsip dasar dalam melaksanakan kegiatannya, perusahaan harus senantiasa memperhatikan kepentingan pemegang saham dan pemangku kepentingan lainnya berdasarkan asas kesetaraan dan kewajaran.

\section{Tujuan dan Manfaat Corporate Governance}

\section{Tujuan Corporate Governance}

Menurut Daniri (2005), bahwa ada 5 macam tujuan utama prinsip Good Corporate Governance, yakni: melindungi hak dan kepentingan pemegang saham; melindungi hak dan kepentingan para anggota the stakeholder non pemegang saham; meningkatkan nilai perusahaan dan para pemegang saham; meningkatkan efisiensi dan efektifitas kerja Dewan Pengurus dan manajemen perusahaan; meningkatkan mutu hubungan dewan pengurus dengan manager senior perusahaan.

\section{Manfaat Good Corporate Governance}

Seberapa jauh perusahaan memperhatikan prinsip-prinsip dasar GCG telah semakin menjadi faktor penting dalam pengambilan keputusan investasi. Terutama sekali hubungan antara praktik corporate governance dengan karakter investasi internasional saat ini. Karakter investasi ini ditandai dengan terbukanya peluang bagi perusahaan mengakses dana melalui 'pool of investors' di seluruh dunia. Suatu perusahaan dan atau negara yang ingin menuai manfaat dari pasar modal global, dan jika kita ingin menarik modal jangka panjang yang, maka penerapan GCG secara konsisten dan efektif akan mendukung ke arah itu. Bahkan jika pun perusahaan tidak bergantung pada sumber daya dan modal asing, penerapan prinsip dan praktik GCG akan dapat meningkatkan keyakinan investor domestik terhadap perusahaan.

Di samping hal-hal tersebut di atas, mengacu pada pendapat Daniri (2005) manfaat GCG antara lain juga dapat: (1) mengurangi agency cost, yaitu suatu biaya yang harus ditanggung pemegang saham sebagai akibat pendelegasian wewenang kepada pihak manajemen. Biaya-biaya ini dapat berupa kerugian yang diderita perusahaan sebagai akibat penyalahgunaan wewenang (wrongdoing), ataupun berupa biaya pengawasan yang timbul untuk mencegah terjadinya hal tersebut. (2) Mengurangi biaya modal (cost of capital), yaitu sebagai dampak dari pengelolaan perusahaan yang baik tadi menyebabkan tingkat bunga atas dana atau sumber daya yang dipinjam oleh perusahaan semakin kecil seiring dengan turunnya tingkat resiko perusahaan. (3) Meningkatkan nilai saham perusahaan sekaligus dapat meningkatkan citra perusahaan tersebut kepada publik luas dalam jangka panjang. (4) Menciptakan dukungan para stakeholder (para pihak yang berkepentingan) dalam lingkungan perusahaan tersebut terhadap keberadaan dan berbagai strategi dan kebijakan yang ditempuh perusahaan, karena umumnya mereka mendapat jaminan bahwa mereka juga mendapat 
manfaat maksimal dari segala tindakan dan operasi perusahaan dalam menciptakan kemakmuran dan kesejahteraan. Manfaat GCG ini bukan hanya untuk saat ini, tetapi juga dalam jangka panjang dapat menjadi pilar utama pendukung tumbuh kembangnya perusahaan sekaligus pilar pemenang era persaingan global.

\section{METODE PENELITIAN}

Dalam penelitian ini peneliti melakukan evaluasi atas penerapan dan pelaksanaan prinsipprinsip good corporate governance yang dilakukan oleh PT Aneka Tambang Tbk. berdasarkan parameter dari OECD pada tahun 2004 dengan tetap memperhatikan landasan teori yang yang telah dituangkan sebagai dasar dalam melakukan evaluasi atas penerapan dan pelaksanaan prinsip good corporate governance. Evaluasi ini bertujuan untuk mengetahui dan menilai kualitas Corporate Governance yang telah dilaksanakan oleh PT Aneka Tambang Tbk, apakah prinsip-prinsip yang diterapkan telah dijalankan secara efektif dalam rangka menciptakan GCG yang baik. Dalam hal ini, peneliti melakukan wawancara serta pengamatan langsung dalam memperoleh informasi yang diperlukan dalam melakukan evaluasi di PT Aneka Tambang Tbk.

Penerapan good corporate governance pada PT. Aneka Tambang sesuai dengan prinsip yang ditetapkan oleh OECD 2004 dicerminkan dengan 5 (lima) aspek namun tetap berdasarkan prinsip dasar transparency, accountability, responsibility, independency, fairness hanya saja dimodifikasi sedikit sehingga dituangkan menjadi aspek-aspek sebagai berikut: hak-hak pemegang saham; perlakuan yang adil terhadap para pemegang saham; peranan stakeholders; keterbukaan atau transparency; tanggung jawab dewan pengurus.

Pada bagian ini peneliti akan mendeskripsikan prinsip-prinsip apa saja yang sudah diterapkan dan dilakukan oleh perusahaan dalam rangka penerapan prinsip good corporate governance dengan cara membandingkan prinsip-prinsip tersebut dengan tetap mengacu pada 5 (lima) prinsip dasar good corporate governance. Berikut ini adalah tabel perbandingan antara penerapan good corporate governance pada PT Aneka Tambang Tbk berdasarkan terhadap prinsip OECD tahun 2004.

\section{HASIL DAN PEMBAHASAN}

Dalam mendukung tercapainya tata kelola perusahaan yang baik diperlukan kerjasama antar semua pihak terutama organ-organ penting yang berkaitan dengan pelaksanaan prinsip-prinsip Good Corporate Governance. Berdasarkan tabel di atas, terlihat ada beberapa perbedaan penerapan prinsip yang terjadi pada PT Antam dengan prinsip OECD 2004. Berikut ini adalah evaluasi terhadap perbedaan subprinsip pada penerapan prinsip Corporate Governance pada Antam dan OECD 2004, yaitu: (1) auditor eksternal harus bertanggung jawab pada pemegang saham dan melaksanakan tugasnya terhadap perusahaan; (2) pemegang saham, termasuk pemegang saham institusi diperbolehkan untuk saling berkonsultasi berkenaan dengan informasi dan hak-hak dasar pemegang saham.

Di bawah ini adalah penjelasan atas perbedaan penerapan prinsip GCG antara Antam dan OECD 2004 beserta rekomendasi serta hambatan atas perbedaan tersebut.

\section{Auditor Eksternal Bertanggung Jawab pada Pemegang Saham}

Auditor eksternal harus bertanggung jawab pada pemegang saham dan melaksanakan tugasnya terhadap perusahaan. Perbedaan antara Antam dengan OECD 2004 adalah tanggung jawab dan tugas auditor eksternal. Mengacu pada OECD tentang salah satu tugas auditor ekternal, auditor 
wajib melaporkan perbedaaan pendapat dengan manajemen perusahaan tentang hasil temuan mereka kepada komite audit yang dibentuk oleh perusahaan. Menurut informasi yang diperoleh, terkadang eksternal auditor di Antam memiliki perbedaan pendapat dengan manajemen perusahaan tentang hasil temuan yang telah diaudit. Perbedaan pendapat tersebut kemudian diselesaikan dan dicari jalan keluarnya sehingga bisa dilaporkan ke komite audit oleh eksternal auditor. Akan tetapi perbedaan pendapat yang belum terselesaikan tidak ikut dilaporkan kepada komite audit.

Hal yang menjadi pertimbangan untuk tidak melaporkan perbedaan pendapat yang belum terselesaikan adalah apabila perbedaan pendapat yang sudah terselesaikan dan belum terselesaikan dilaporkan secara bersama kepada komite audit, ditakutkan akan berpengaruh terhadap hasil audit yang akan dikeluarkan oleh komite audit untuk kemudian dilaporkan kepada pemegang saham. Dampak yang ditimbulkan atas perbedaan yang terjadi adalah dampak negatif dengan tidak disampaikannya perbedaan pendapat yang belum terselesaikan ke komite audit, maka hasil audit belum bisa dikeluarkan kepada pemegang saham; serta dampak positif kesalahan ataupun resiko yang terjadi pada hasil temuan audit bisa lebih diminimalisir guna menghasilkan audit laporan keuangan yang sesuai.

Rekomendasi yang dapat penulis berikan adalah: (1) perbedaan pendapat sehubungan dengan temuan hasil audit harus langsung diselesaikan dan dicari jalan keluarnya untuk menghindari resiko yang akan terjadi dalam audit berikutnya; (2) perbedaan pendapat yang belum sesuai hendaknya tetap dilaporkan pada komite audit guna dicari jalan keluarnya sehingga menghasilkan hasil yang sesuai.

\section{Pemegang Saham Berkonsultasi tentang Informasi dan Hak Dasar Pemegang Saham}

Pemegang saham, termasuk pemegang saham institusi diperbolehkan untuk saling berkonsultasi berkenaan dengan informasi dan hak-hak dasar pemegang saham. Perbedaan antara Antam dengan OECD 2004 adalah konsultasi pemegang saham berkenaan dengan informasi dan hakhaknya sebagai pemegang saham. Pemegang saham sebagai pemilik modal memiliki hak dan tanggung jawab atas Perseroan sesuai dengan peraturan perundang-undangan dan anggaran dasar Perseroan. Salah satu hak pemegang saham adalah memperoleh informasi lengkap mengenai kegiatan dan kondisi perusahaan secara transparan, akurat dan tepat waktu. Menurut informasi, Antam memperbolehkan seluruh pemegang sahamnya untuk berkonsultasi kepada para pemangku kepentingan perusahaan guna memperoleh informasi dan mengetahui akan hak-haknya di perusahaan.

Hal yang menjadi pertimbangan Antam dalam hal konsultasi pemegang saham adalah dengan adanya konsultasi kepada para pemangku kepentingan seperti Komisaris maupun Direksi, diharapkan pemegang saham mendapatkan informasi lebih terkait dengan kepemilikan sahamnya di perusahaan. Dampak yang terjadi terkait konsultasi pemegang saham adalah dampak positif pemegang saham jadi lebih mengetahui mengenai informasi yang berkaitan dengan kepemilikan sahamnya di perusahaan.

\section{PENUTUP}

Berdasarkan hasil penelitian dan pembahasan atas penerapan prinsip-prinsip Good Corporate Governance di PT Aneka Tambang Tbk, maka peneliti dapat memberikan kesimpulan sebagai berikut: (1) PT Aneka Tambang Tbk telah melakukan revisi atas Pedoman Kebijakan Tata Kelola Perusahaan pada tahun 2008; (2) dalam hasil temuan audit, auditor eksternal terkadang masih memiliki perbedaan pendapat dengan manajemen perusahaan; (3) proses pemilihan auditor eksternal dan auditor internal serta pengangkatan Dewan Komisaris dan Direksi dilaksanakan secara transparan dan telah mendapat persetujuan dari seluruh anggota RUPS dan pemangku kepentingan perusahaan sesuai dengan peraturan yang telah ditetapkan; (4) pelaksanaan prinsip GCG di PT Aneka Tambang telah diterapkan dengan baik sesuai prinsip yang ditetapkan oleh OECD 2004, meskipun ada beberapa kerangka dari prinsip OECD 2004 yang belum dilaksanakan; (5) PT Aneka Tambang sudah memiliki 
divisi khusus yang menangani Good Corporate Governance, yaitu Corporate Secretary. Dengan adanya divisi ini, kerangka perkembangan GCG pada PT Aneka Tambang sudah berjalan efektif terbukti dengan terlaksananya prinsip GCG yang baik dan optimal; (6) akses informasi untuk para pemegang saham dan pemangku kepentingan Perusahaan telah tersedia dan disajikan dengan lengkap, akurat dan tepat waktu melalui berbagai media seperti website, media publikasi, dan media massa; (7) pengelolaan perusahaan menjadi lebih baik dan nilai perusahaan semakin meningkat dengan diterapkannya prinsip GCG di PT Aneka Tambang Tbk.

\section{Saran}

Dari hasil evaluasi yang telah dilakukan terhadap PT Aneka Tambang Tbk, penulis memberikan beberapa saran yang dapat dijadikan pertimbangan dan masukan yang bermanfaat bagi PT Aneka Tambang Tbk dalam menerapkan prinsip-prinsip Good Corporate Governance secara maksimal: (1) perbedaan pendapat yang terjadi terkadang terjadi antara auditor eksternal sebaiknya segera dilaporkan sehingga bisa dicari jalan keluar dari permasalahan yang ada; (2) auditor beserta manajemen perusahaan sebaiknya melakukan pengungkapan potensi resiko terhadap kegiatan yang sedang dijalankan agar dapat dengan mudah ditemukan bagaimana cara menangani dan mengevaluasi resiko yang terjadi; (3) seiring dengan berjalannya waktu, kebijakan pemerintah, dan lingkungan bisnis yang berubah-ubah diharapkan Perusahaan selalu melakukan revisi terhadap semua jenis panduan pedoman yang ada. Perbaikan ini semata-mata upaya dalam menuju kesempurnaan penerapan prinsip-prinsip GCG pada PT Aneka Tambang Tbk.

\section{DAFTAR PUSTAKA}

BAPEPAM. (2006). Studi penerapan prinsip-prinsip OECD 2004 dalam peraturan Bapepam mengenai corporate governance. Diunduh pada 4 April 2010, dari http://www.bapepam.go.id/pasar_modal/publikasi_pm/kajian_pm/studi-2006/studipenerapan-oecd.pdf

Daniri M. A. (2005). Good Corporate Governance: Konsep dan Penerapannya di Indonesia. Jakarta: Ray Indonesia, , 2005.

FCGI, (n.d.). Latar Belakang Pemunculan Good Corporate Governance, diunduh dari http://www.fcgi.or.id/governance/about-good-corporate-governance.html.

Komite Cadburry (1992) Report on the Financial Aspects of Corporate Governance, London: Gee.

Rezaee, Z. (2007). Corporate Governance Post Sarbanes-Oxley. Hoboken: John Wiley \& Sons, Inc.

Shleifer, A., \& Vishny, R.W. (1997). A Survey of Corporate Governance, Journal of Finance 52, 2, 737-783

Tangkilisan, H. N. S. (2003). Manajemen Keuangan bagi Aplikasi Kredit Perbankan, Mengelola Kredit Berbasis Good Corporate Governance. Yogyakarta: Penerbit Balairung.

Tjager, I. N. (2003). Corporate governance: Tantangan dan kesempatan bagi komunitas bisnis Indonesia. Jakarta: Prenhalindo. 